\title{
Natural diet and feeding habits of a freshwater prawn (Macrobrachium carcinus: Crustacea, Decapoda) in the estuary of the Amazon River
}

\author{
Jô de Farias LIMA ${ }^{*}$, Jamile da Silva GARCIA², Thibério Carvalho da SILVA ${ }^{3}$ \\ $1^{*}$ Empresa Brasileira de Pesquisa Agropecuária - Embrapa Amapá. Rodovia Juscelino Kubitschek, km 5, n²600, CEP: 68906-970, Caixa Postal 10, Phone: (96) 4009-9546, \\ Fax: (96) 4009-9501. Macapá, Amapá, Brazil. \\ 2 Universidade do Estado do Amapá. Av. Presidente Vargas, nº 650, CEP: 68900-000. Macapá, Amapá, Brazil. milyeminem@hotmail.com \\ 3 Universidade Estadual do Oeste do Paraná - Unioeste/Toledo. Grupo de Estudos de Manejo na Aquicultura - GEMAq. Rua da Faculdade, 645. Jd. Santa Maria, CEP 85903-160. \\ Toledo, Paraná, Brazil. thiberiocs@hotmail.com \\ * Corresponding Author: jo.lima@embrapa.br
}

\begin{abstract}
Macrobrachium carcinus is a Brazilian native prawn with recognized potential for use in aquaculture activities. However, there is little information about the natural diet and feeding habits of this species. The aim of this study was the identification of the diet items of $M$. carcinus based on the analysis of the stomach contents. Specimens were collected in the Amazon River estuary between January 2009 and January 2010. The stomach analysis was carried out by using the frequency of occurrence (FO), methods of points (MP) and feeding index (FI). It was observed that prawns fed on detritus, animals and plant fragments as the most important food items. Sediment accounted for the main stomach content, accounting for $43.2 \%$ by the MP, $44.9 \%$ by FI and $100 \%$ by the FO. Sexual differences in feeding preferences were not found in this study, and seasonal differences in the frequency of items ingested by $M$. carcinus were not observed. The results indicated that $M$. carcinus can be considered omnivorous species, but with an important carnivorous component, similar to that found in other Macrobrachium species.
\end{abstract}

KEYWORDS: food, stomach morphology, pitu, sand ingestion, palaemonid

\section{Dieta natural e hábito alimentar de um camarão de água doce (Macrobrachium carcinus: Crustacea, Decapoda) no estuário do rio}

\section{Amazonas}

\begin{abstract}
RESUMO
Macrobrachium carcinus é uma espécie nativa com reconhecido potencial para ser utilizada na aquicultura, devido seu grande porte e seus bons índices de fecundidade e fertilidade. Apesar de seu evidente potencial para cultivo, poucas informações sobre dieta natural e habito alimentar desta espécie são conhecidos na literatura. O objetivo principal deste estudo foi identificar os itens da dieta natural de $M$. carcinus, com base na análise de conteúdo estomacal de espécimes coletados no estuário do rio Amazonas entre janeiro de 2009 e janeiro de 2010. A análise do conteúdo estomacal foi feita usando frequência de ocorrência (FO), método de pontos (MP) e índice alimentar (FI). Os dados revelaram que os componentes alimentares mais importantes desta espécie foram detrito, fragmentos animais e vegetais. $\mathrm{O}$ item sedimento constituiu o maior componente do estômago com 43,2\% pelo MP, 44,9\% pelo FI e 100\% pela frequência de ocorrência, respectivamente. Diferenças sexuais entre as preferências alimentares sobre os alimentos náo foram encontrados no presente estudo. Diferenças sazonais na frequência de itens ingeridos por $M$. carcinus não foram observados. Os resultados indicaram que $M$. carcinus pode ser considerado como um onívoro, mas com um componente importante carnívoro, semelhante ao encontrado em outras espécies de Macrobrachium. Outros aspectos sobre o hábito alimentar e morfologia do estômago são brevemente discutidos.
\end{abstract}

PALAVRAS-CHAVE: alimento, morfologia do estômago, pitu, ingestão de areia, palaemonideo. 


\section{INTRODUCTION}

Among freshwater prawns, the genus Macrobrachium (Bate1868) (Palaemonidae) has been globally identified as foremost in terms of economic importance and possibility of recruitment into aquaculture, distributed in the tropical and subtropical regions (Silva et al. 2007). Macrobrachium carcinus (Linnaeus 1758) is one of the largest freshwater prawns worldwide as it can reach $300 \mathrm{~mm}$ in length. It has high economic importance and potential to be used in prawn farming (Holthuis 1980). Macrobrachium carcinus occurring from southern United States to Brazil (from Amapá to Rio Grande do Sul) (Holthuis 1952, 1980; Duncan et al. 1975) in rivers flowing the Atlantic Ocean.

Despite being widely exploited by artisanal fisheries in northern and northeastern Brazil and showing great potential for aquaculture, few data on the natural diet and feeding habits of $M$. carcinus are available. The knowledge of the diet and feeding habits of a species in nature is important for the establishment of its nutritional needs and interactions with other organisms (Chaves and Umbria 2003, Albertoni et al. 2003). Food and feeding habits are indispensable part of biological and taxonomic studies, once essential functions of an organism as growth, development and reproduction are all dependent on the energy that enters as food (Wootton 1992).

The majority of studies on feeding habits of prawns have been focused on penaeid (Marte 1980; Chong and Sasekumar 1981; Cortés and Criales 1989/1990). The analysis of stomach contents provide important information about the feeding habits of the species; also it gives evidence of their trophic position in a community and can reveal the preferred food items or the most used (Fonteles-Filho 1989; Chaves and Umbria 2003). Investigations regarding the feeding biology of Macrobrachium prawns remain scarce, being limited to some reports by Collins and Paggi (1998) on M. borelli; Albertoni et al. (2003) on M. acanthurus and Abayomi et al. (2011) on M. vollenhovenii.

Some authors have shown that Palaemonidae species has a varied diet composed by several items, especially detrital items that are usually important and quite common components (Howard 1984; Collins and Paggi 1998). Kawakami and Vazzoler (1980) proposed one index to evaluate the importance of the dietary items for a given species, using the proportions of frequency of occurrence and volume of each dietary item. This index has been used for some authors (Andrian and Barbieri 1996; Branco et al. 1997, Branco and Verani 1997) and it allows for a fine distinction of the relative importance of each feeding item, whatever its condition regarding the frequency of occurrence and volume. The aims of this study were the identification and quantifications of the diet items and feeding habits and to describe general aspects of stomach morphology of the $M$. carcinus specimens sampled in the Amazon River estuary.

\section{MATERIALS AND METHODS}

\section{Study area}

The study area comprised the regions of Ilha de Santana (0003'40.9"S and 051'08'46.6”W), Mazagão Velho (00¹5'39.9'S and 051'20'42.3'W), Ilha Pequena (00015'20.0"S and 051'18'10.6"W) and Ilha Rasa (00'16'08.1"S and $\left.051^{\circ} 07^{\prime} 25.9^{\prime \prime} \mathrm{W}\right)$, located at the mouth of the Amazon River, between states of Pará and Amapá (Figure 1 ). The areas studied are relatively similar and important to prawn artisanal fishing (Lima et al. 2013). Their general landscape show various drainage channels, with varying sizes and depths allowing the daily flooding and formation of a wide diversity of micro-habitats. In the Ilha de Santana, vegetation is open and sparely, with the presence of a narrow border of macrophytes. In Ilha Pequena and Ilha Rasa, vegetation is moderately dense with some wide bands of macrophytes occupying its edge. In the Mazagáo Velho, vegetation is strongly dense with great and wide bands of macrophytes along of the river.

\section{Collection and treatment of samples}

Samples were collected monthly from January 2009 to January 2010 by using a handcrafted trap called "matapis" (30 cm in diameter and $50 \mathrm{~cm}$ in length), baited with flour of babaçu fruit (Orbignya speciosa) (Simonian 2006; Lima et al. 2013). The flour of babaçu was protected with small cloth bags to avoid ingestion. Ten matapis were used at each collection site. Traps were set at depths of 1 to 2 meters, during on average of 12 hours of immersion. This sampling is equivalent to the capture performed by artisanal fishermen, which took place every tidal cycle (12h, twice daily). All captures occurred at daybreak. The specimens captured were immediately placed into plastic bags containing formalin solution (10\%) and ethanol $(70 \%)$ at $1: 1$ ratio.

The sex was checked by the presence of appendix on the second pleopods of male. Total wet weight (WW), Total length (TL) measured by linear distance from the rostrum extremity to the telson tip and standard length (SL) accessed by linear distance from base of ocular orbit to base of the telson (abdomen + carapace lengths) was obtained to describe biometric relationships with feeding habits (Figure 2).

\section{Feeding and analysis of stomach contents}

In the laboratory, ten $M$. carcinus specimens were maintained alive in freshwater aquaria, utilizing PVC pipes $(50 \mathrm{~mm})$ as refuge and fine sand as substrata. The feeding procedures were observed on five individuals during 1 hour, three times a day, and totaling 12 hour. Food as fish pieces 


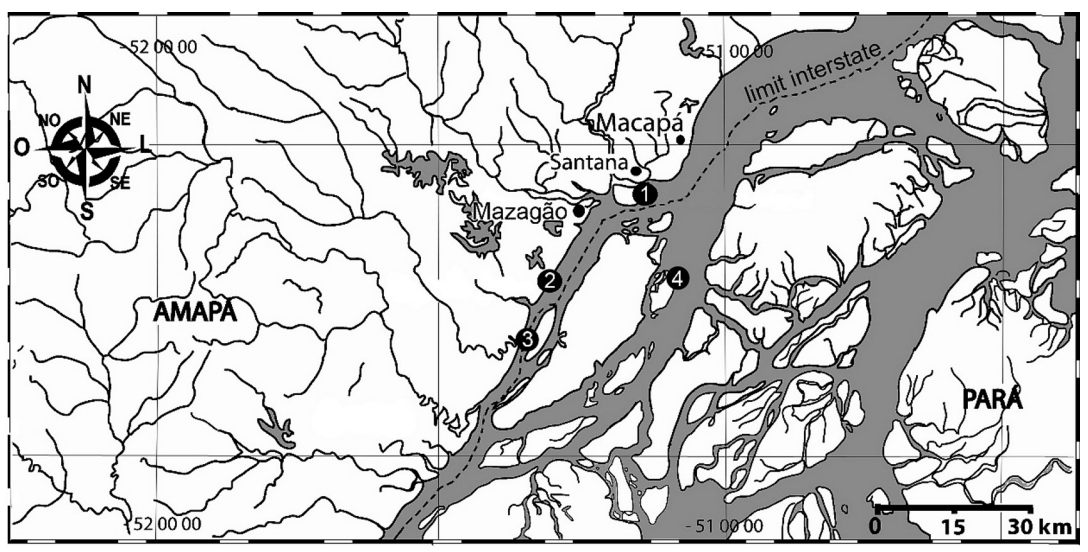

Figure 1 - Study area location and collection sites. 1- Ilha de Santana; 2 - Mazagão Velho; 3 - Ilha Pequena; 4 - Ilha Rasa.

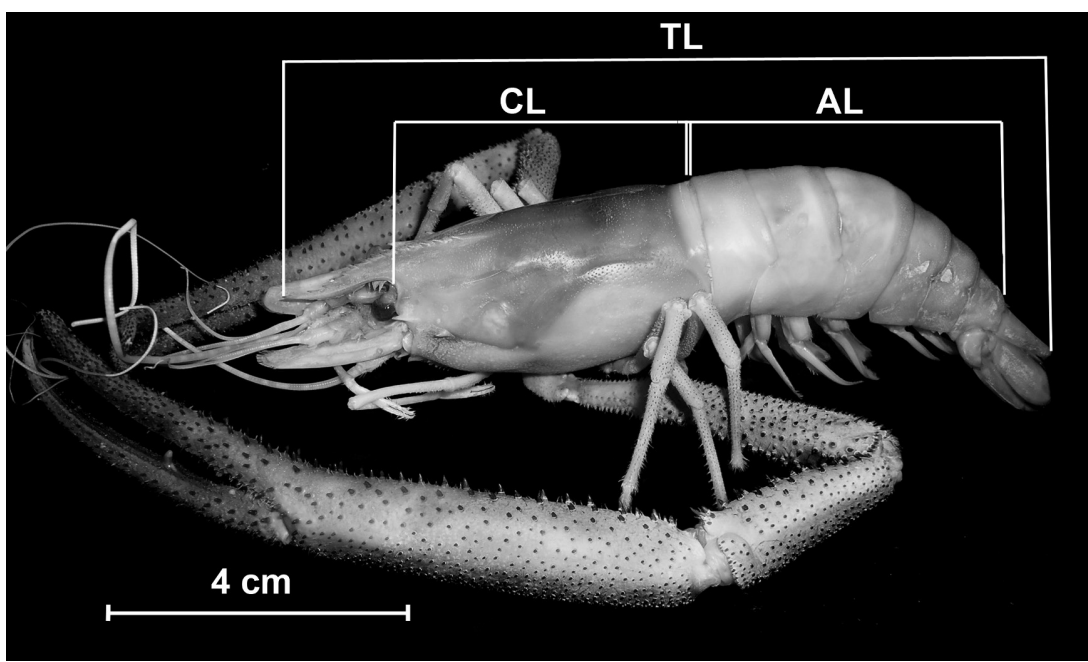

Figure 2 - Body parts dimensions for Macrobrachium carcinus. CL - carapace length; $T L$ - total length; AL - abdomen length.

and prawns were offered during feeding observations. Adult of both sexes and juvenile prawns were dissected. The stomachal content was dumped on a counting chamber; the items were separated and identified to the smaller taxonomic unit as possible.

Food items were grouped into seven categories: Sediment (coarse sandy grain and fine sandy grain); Detritus (rigid material of Animal and Plant); Plantae (residues seeds, leaves and roots); Crustacea (pieces of mouth appendages, chelae, rostrum, cephalothoraxes, telsons, uropods and exuviae from recent molts and setae); Foraminiferida (small pieces) and Nematoda (small pieces). The gut content of $M$. carcinus was not possible to be identified; hence it was called Unidentified Material-UNM. The empty guts were not considered in the estimates of frequency of dietary items, only in the estimates of relative degree of fullness. During dissections almost general aspects of stomach morphology (presence of gastric mill, ossicles or teeth) were observed to facilitate the understanding of their feeding habits.

Relative degree of fullness was assessed visually and due to the small size each stomach was categorized according to Barutot et al. (2011) as follows: class 1 (with less than 25\% full or only a trace of content); class 2 (with less than $50 \%$ but more than $25 \%$ of content); class 3 (with less than $75 \%$ but more than $50 \%$ of content); class 4 (with more than $75 \%$ to $100 \%$ of content). The relative contribution of each stomach content category was subjectively assessed on a rank score: the category representing 95 to $100 \%$ of stomach content was given 100 points; more than 65\% and less than 95\% with 75 points; less than $65 \%$ and more than $35 \%$ with 50 points and stomachs with less than 35 and more than $5 \%$ was given 25 points. The number of points each category received was 
weighted according to the stomach fullness in which they were found. This weighting consisted of multiplying the number of points by a value dependent on the class of fullness: Class $4=1.0$; Class $3=0.6$; Class $2=0.2$.

The contribution of each item was quantitatively estimated through the Method of Points (Williams 1981). The frequency of occurrence of each item was determined (Hynes 1950). For comparison and better comprehension of the importance of each trophic category, the feeding index (FI) was used as proposed by Kawakami and Vazzoler (1980) that combines both methods. Parallelograms of the importance of the groups of dietary items were constructed with the obtained data. A figure combining the volume percentage in the $x$ - axis and frequency of occurrence percentage in the $y$ - axis represents the relative importance of the food items:

$\mathrm{FIi}=\mathrm{Fi} \times \mathrm{Vi} / \mathrm{L}(\mathrm{Fi} \times \mathrm{Vi})$, where:

$\mathrm{Fi}$ = frequency of occurrence (percentage) of "i" item

$\mathrm{Vi}=$ volume (percentage) of "i" item

The differences between frequencies of occurrence of the items consumed by males and females were analyzed and tested using a Chi-square ( $\chi 2$ ) test (Zar 1996). Normality was assessed using the Kolmogorov-Smirnov test (Zar 1996). Seasonal and sites comparisons were performed using the ANOVA test. Differences in the frequency of occurrence of food items between size classes were assessed using the ANOVA test.

\section{RESULTS}

\section{Natural diet}

A total of 254 specimens were analyzed, 104 from Santana Island, 67 from Pequena Island, 48 from Rasa Island and 35 from Mazagáo Velho, totaling 120 males and 134 females. Among the 254 stomachs examined, 132 were class I or empty, 59 in class IV, 25 in class III and 38 class II or partially filled

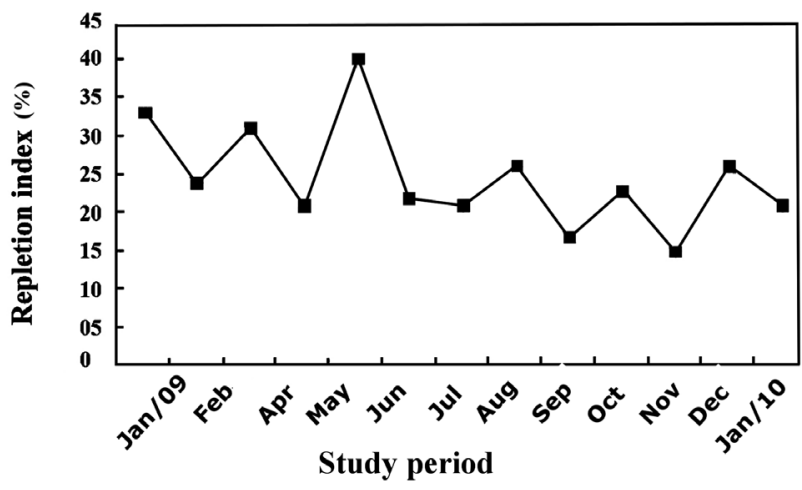

Figure 3 - Stomachal seasonal repletion index of Macrobrachium carcinus specimens sampled in the Amazon River estuary from January 2009 to January 2010.
Table 1 - Frequency of occurrence distribution of males and females of Macrobrachium carcinus with contents and empty stomachs sampled in the Amazon River estuary from January 2009 to January 2010

\begin{tabular}{lccccc}
\hline & \multicolumn{4}{c}{ Stomachs } & \\
\cline { 2 - 5 } & \multicolumn{3}{c}{ Empty } & \multicolumn{3}{c}{ With contents } & \\
\hline Sex & $\mathrm{N}$ & $\%$ & $\mathrm{~N}$ & $\%$ & Total \\
Male & 59 & 49.2 & 61 & 50.8 & 120 \\
Female & 73 & 54.5 & 61 & 45.5 & 134 \\
\hline
\end{tabular}

Table 2 - Differences between food items consumed by males and females of Macrobrachium carcinus sampled in the Amazon River estuary from January 2009 to January 2010

\begin{tabular}{lccc}
\hline \multirow{2}{*}{ Food Item } & Males & Females & \multirow{2}{*}{$\chi^{2}$} \\
\cline { 2 - 3 } & M.P $(\%)$ & M.P $(\%)$ & \\
\hline Sediment & 43.8 & 42.5 & 0.02 \\
\hline Detritus & 15.6 & 16.0 & 0.0049 \\
Plantae & 13.2 & 13.4 & 0.0027 \\
Unidentified & 11.4 & 11.8 & 0.01 \\
Material (UNM) & 15.8 & 16.2 & 0.0032 \\
Crustacea & - & 0.05 & 0.05 \\
\hline Foraminiferida & 0.045 & - & 0.045 \\
Nematoda & 100 & 100 & \\
\hline \multicolumn{1}{c}{ Total } & & & \\
\hline
\end{tabular}

Table 3 - Number of stomachs with food items, frequency of occurrence, volume (percentage) and feeding index (FI) of food items consumed by Macrobrachium carcinus specimens sampled in the Amazon River estuary from January 2009 to January 2010. Abbreviations: UNM - Unidentified Material.

\begin{tabular}{lcccc}
\hline \multicolumn{1}{c}{$\begin{array}{c}\text { Alimentary } \\
\text { Item }\end{array}$} & $\begin{array}{c}\mathrm{N}^{0} \text { stomachs } \\
\text { with Item }\end{array}$ & $\mathrm{FO}(\%)$ & $\mathrm{MP}(\%)$ & $\mathrm{Fl}(\%)$ \\
\hline Sediment & 122 & 100 & 43.2 & 44.9 \\
Detritus & 111 & 90.9 & 15.8 & 14.9 \\
Plantae & 115 & 94.4 & 13.3 & 12.9 \\
UNM & 116 & 95.1 & 11.6 & 11.4 \\
Crustacea & 115 & 94.3 & 16.1 & 15.7 \\
Foraminiferida & 1 & 0.82 & 0.02 & 0.0002 \\
Nematoda & 1 & 0.82 & 0.02 & 0.0002 \\
\hline
\end{tabular}

out (Table 1). Mean stomach repletion index of $M$. carcinus showed little oscillation during the months studied (Figure 3). There was little variation in the sex ratio. In most samples, a moderate predominance of females was found, with males to female ratio of $1: 1.12\left(\chi_{\text {cal }}^{2}=0.77, \mathrm{df}=2 ; \chi_{\text {tab }}^{2}=3.84, \mathrm{p}>0.05\right)$.

The $\chi^{2}$ test revealed no significant differences between the feeding preferences of males and females ( $p>0.05)$ for the food items found in the present study (Table 2). The items Detritus, Crustacea, Plantae followed by the unidentified material constituted the most important food items occurring in every stomach of $M$. carcinus examined (Table 3 ). Despite the Sediment not being considered as a food item, it forms the 

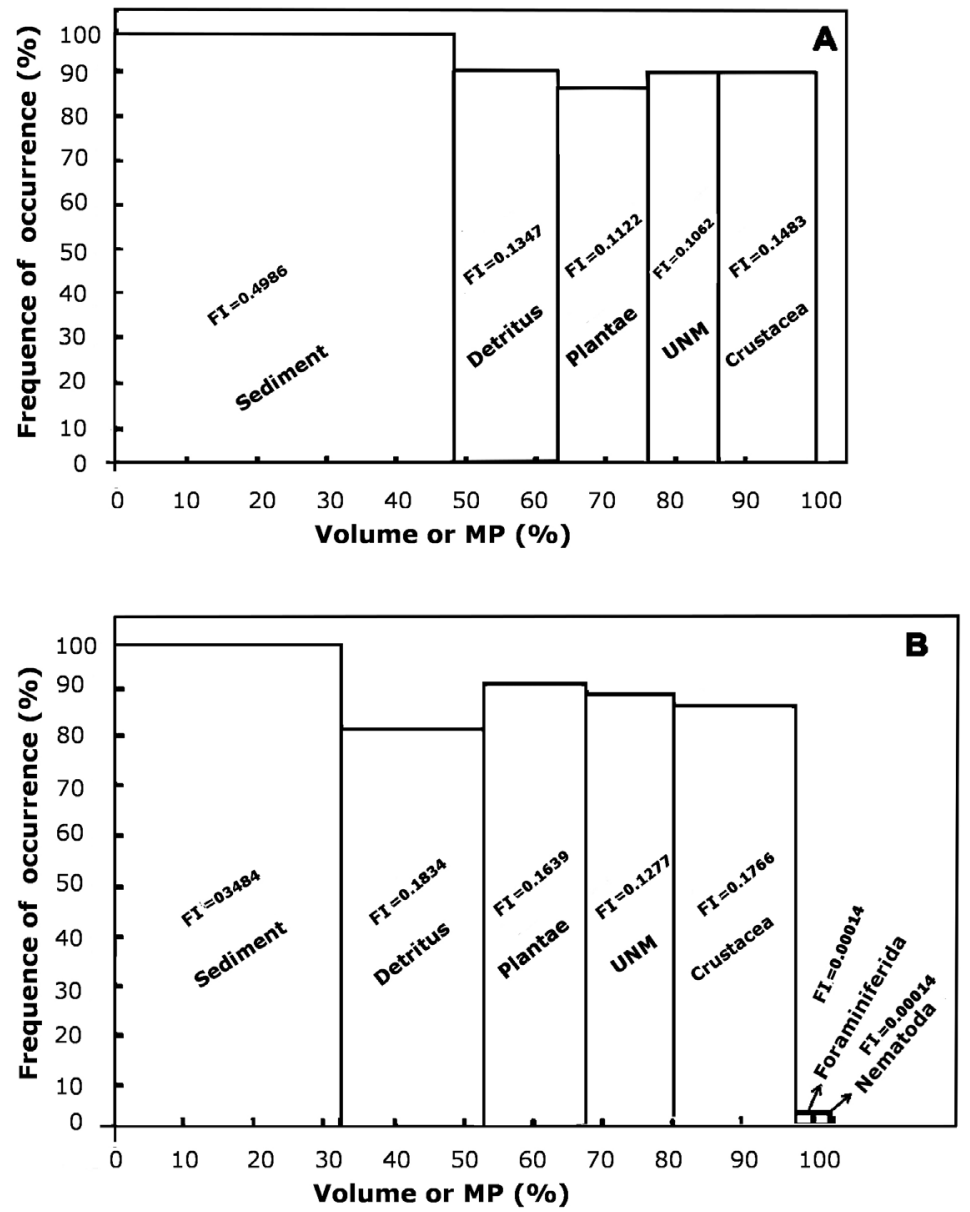

Figure 4 - Importance of the food items by frequency of occurrence, volume or MP (percentage) and feeding index (FI) consumed by Macrobrachium carcinus specimens sampled in the Amazon River estuary from January 2009 to January 2010. A - Rainy season; B - Dry season

Table 4 - Frequency of occurrence (FO\%) food items consumed of the dietary items by Macrobrachium carcinus with different class standard length. Abbreviations: UNM - Unidentified Material.

\begin{tabular}{|c|c|c|c|c|c|c|c|}
\hline \multirow{2}{*}{$\begin{array}{c}\text { Size } \\
\text { Class }\end{array}$} & \multicolumn{7}{|c|}{ Alimentary Item } \\
\hline & Sediment & Detritus & Plantae & UNM & Foramiferida & Crustacea & Nematoda \\
\hline $39-49$ & 100 & 100 & 100 & 100 & 50 & 100 & 50 \\
\hline $49-59$ & 66.7 & 50 & 66.7 & 33.3 & - & 50 & - \\
\hline $59-69$ & 58.3 & 50 & 58.3 & 58.3 & - & 58.3 & - \\
\hline $69-79$ & 38.5 & 34.6 & 38.5 & 38.5 & - & 34.6 & - \\
\hline $79-89$ & 50 & 43.7 & 50 & 46.9 & - & 50 & - \\
\hline $89-99$ & 60.6 & 57.6 & 54.5 & 60.6 & - & 54.5 & - \\
\hline $99-109$ & 36.4 & 34.1 & 36.4 & 36.4 & - & 34.1 & - \\
\hline $109-119$ & 50 & 41.7 & 41.7 & 47.2 & - & 50 & - \\
\hline $119-129$ & 38.1 & 33.3 & 38.1 & 38.1 & - & 38.1 & - \\
\hline $129-139$ & 50 & 41.7 & 41.7 & 33.3 & - & 50 & - \\
\hline $139-149$ & 50 & 50 & 43.7 & 50 & - & 37.5 & - \\
\hline $149-159$ & 57.1 & 57.1 & 57.1 & 57.1 & - & 57.1 & - \\
\hline $159-169$ & 50 & 50 & 50 & 50 & - & 50 & - \\
\hline $169-179$ & 40 & 40 & 40 & 40 & - & 40 & - \\
\hline
\end{tabular}


major constituent of the stomach accounting for $43.2 \%$ (MP), $44.8 \%(\mathrm{FI})$ and $100 \%$ (FO), respectively. Foraminiferida and Nematoda parts were found in the stomach and accounted for $0.02 \%(\mathrm{MP})$ and $0.82 \%(\mathrm{FO})$, indicating that these are occasional items in the diet of $M$. carcinus from Amazon River estuary. The food items Plantae, Crustacea, Detritus and UNM showed little variation in the frequency of occurrence concerning to seasonality indicating that both are available throughout the year in the areas studied.

The ANOVA test used to verify seasonal differences in the frequency of items ingested by $M$. carcinus indicated no significant differences ( $\mathrm{p}>0.05)$, according MP. On the other hand, the ANOVA test showed significant differences $(p<0.05)$ in the FO of food items between different size classes, showing that the smaller prawns $(\mathrm{TL}<49 \mathrm{~mm}$ ) are fed on greater frequency than adults. Parallelograms of the importance of the groups of dietary items are shown in Figure 4 A, B. Frequency of occurrence (FO \%) of the dietary items by size class of $M$. carcinus is shown in Table 4 .

\section{Feeding}

The food is collected by the chelipeds of pereiopods, which flex toward the third maxillipeds. The third maxillipeds manipulate the food between their distal endopodal segments. The second maxillipeds collect material from the endopods of the third maxillipeds. Particles are then transferred by the second maxillipeds to the inner mouthparts where they are sorted prior to ingestion. Particles rejected may be further masticated by the second and third maxillipeds, or discarded into a water current produced by the rapidly beating exopod flagella of the second and third maxillipeds. Despite the tearing action between the jaws pronounced maxillipeds and third pieces of shrimp are generally eaten as a continuous length up to $10 \mathrm{~mm}$ can be pulled out of the stomach intact. The gut contents of animals obtained in the field also included these strips of flesh and thus the food entering the gut is not often well masticated.

\section{Gross morphology of stomach}

Morphologically, the stomach of $M$. carcinus is completely distinct from penaeid shrimps. The cardiac sac is expanded in direction to posterior region of the carapace and covers completely the pyloric stomach. The gastric mill and other structures to maceration are absent in the cardiac stomach. The cardiac floor is smooth and slightly concave, with two rows of numerous elongated setae arranged laterally (Figure 5).

\section{DISCUSSION}

The knowledge of the diet of a species in nature is important for the establishment of its nutritional needs and the interaction with other organisms (Albertoni et al. 2003)

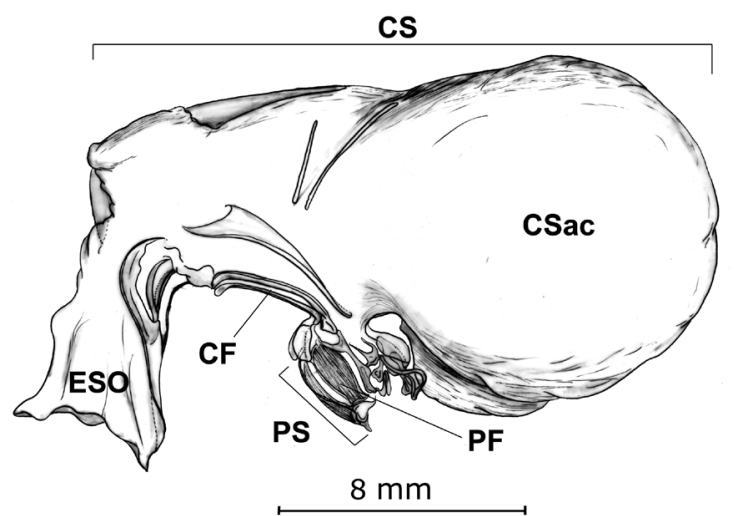

Figure 5 - Stomach's lateral view of Macrobrachium carcinus specimens sampled in the Amazon River estuary from January 2009 to January 2010. Abbreviations: ESO - esophagus; CF - cardiac floor; CS - cardiac stomach; PS - pyloric stomach; PF - pyloric filter and CSac - cardiac sac.

and it is an important tool for evaluating the structure and functioning of ecosystems (Krebs 1989). Decapod crustaceans have been described as opportunistic omnivores, taking their food from the bottom of their habitats or from the fauna associated with submerged and shore vegetation in the water bodies (Williams 1981; Jayachandran and Joseph 1989). Some authors have shown that species of Palaemonidae also had a diet composed by several items, although the detritus was usually important and a quite common component (Howard 1984; Roy and Singh 1997; Collins and Paggi 1998).

The feeding indices showed detritus, animals and vegetable fragments as main components of the natural diet of $M$. carcinus in the estuary of the Amazon River. According to Lewis et al. (1966) M. carcinus is a prawn that ingests high percentage of detritus (77\%) especially in the juvenile prawns, which is not evident in this study. Our results indicate that $M$. carcinus is omnivorous, but with an important carnivorous component, similar to that found in other species of Macrobrachium, such as $M$. amazonicum (Odinetz-Collart 1988), M. lamarrei (Sharma and Subba 2005), M. acanthurus (Albertoni et al. 2003) and M. vollenhovenii (Jimoh et al. 2011).

Lewis et al. (1966) reported algae, detritus, animal and vegetable fragments in the stomach of $M$. carcinus; plant material was represented by leaves and stems of aquatic plants and seeds of various types; while animal items were represented by aquatic insects, fish, mollusks and other crustaceans. In this study, food items as algae, mollusks, fish and insects were not identified; probably due to the high degree of digestion and fragmentation, consequently some of these items were occasionally identified as detritus or UNM. In this context, food items as algae, mollusks, fish and insects should not be 
excluded from the natural diet of $M$. carcinus populations in the Amazon River.

The analysis of feeding items by the method of points (numerical) and frequency occurrence can provide indication of the preference for one or more food categories within the population studied (Hyslo 1980). Considering that the MP and $\mathrm{FO}$ percentages were statically similar for diet items in the present study, the $M$. carcinus populations from Amazon River estuary probably are using the same food source and have feeding homogeneity within the population.

The feeding habits of palaemonid prawns are related to changes in their life cycle as diet changes appreciably with increasing size of the individuals (Inyang 1978; Guerao 19931994, 1995; Guerao and Ribera 1996). In the present study juvenile prawns ( $\mathrm{TL}<49 \mathrm{~mm}$ ) is fed on greater frequency than adults, probably because they are more active. Lewis et al. (1966) observing the feeding habits of M. carcinus in concrete tanks concluded that juveniles of this species feed most actively at night.

The well-coordinated characteristic of tearing foods between the third maxillipeds and mandibles in M. carcinus was similar to that described in penaeid shrimps (Suthers 1984; Felgenhauer and Abele 1989; Garm 2004) and other macrophagous decapods as hermit crabs and portunids (Kunze and Andeson 1979, Salindeho and Johnston 2003). The degree of involvement of the individual mouthparts in these functions differs between species, although food sorting and ingestion by the first maxillipeds, maxillae and maxillules are generally similar for all species. Still, the stomach of decapods has a general gradation of increasing complexity in size, shape and number of ossicles from the Penaeidea to the Brachyura documented by Meiss and Norman (1977), Alexander $e t a l$. (1980), Suthers (1984) and others. The presence and action of the gastric mill, typical of many decapods (e.g. Kunze and Anderson 1979), was not observed in this study, not being a universal characteristic. For example, the gastric mill is absent in Macrobrachium; however the food trituration and digestion occurs normally at the level of the stomach and not only by the mechanical action of the mandibles as reported by Meiss and Norman (1977) and others.

The grinding surfaces of the lateral teeth, typical of peneid shrimps, is absent in $M$. carcinus and the food trituration is feasible only because of the large amount of sand in the diet, along with gastric juices and the motion of the cardiac stomach. As suggested by Coombs and Allen (1978) for the carid Hippolyte varians, the macerating action in M. carcinus is similar to that of a gizzard. Such a mechanism is capable of digesting large fleshy pieces indicating that food maceration in M. carcinus occurs in mandibles and stomach. The relationship of an omnivorous diet to the robust mouthparts and absent gastric mill is comprehensible within this functional context.
The presence of sand and other sediments in the stomach of Decapoda crustaceans has been reported by many authors, especially by accidental ingestion with preys (Branco and Moritz-Junior 2001; Branco and Lunardon-Branco 2002; Abayomi et al. 2011). In M. carcinus, the sand ingestion can occur as a carbonate source or to help in the food maceration in response to the absence of gastric mill in the stomach, common in Macrobrachium species.

During the feeding function, as described in this study, detritus is swept into the oesophageal region while sand and other indigestible items fall between the slightly rubbing and sorting third maxillipeds. Consequently, the large amount of grit in the diet could not be accidental with the sorting action of mouthparts. This lack of mastication by the mouthparts and the large proportion of sand shown in this study are important factors to be considered in the context of digestive function. The intentional or accidental sand ingestion and their effects on growth and survival of $M$. carcinus need to be tested.

\section{CONCLUSIONS}

Macrobrachium carcinus is omnivorous, but with an important carnivorous component. Data presented in this study indicate that $M$. carcinus has not food preference between sexes. Stomach morphology of adult and juvenile specimens of $M$. carcinus is similar; however the juveniles are fed on greater frequency than adults. The stomach's general morphology indicated that the sand ingestion by M. carcinus probably occurs to help in the food maceration in response to the absence of gastric mill or teeth in the stomach.

\section{ACKNOWLEDGMENTS}

We are grateful to God Almighty for the strength, knowledge and wisdom in researching and writing this article. Special thanks to the Empresa Brasileira de Pesquisa Agropecuária for having supported the project MP3 1/2008 - No 03081470000, whose research data provided basis for developing this work. We greatly thank to Instituto Chico Mendes de Conservaçáo da Biodiversidade for the collect authorization (SISBIO no 17702).

\section{REFERENCES}

Abayomi, A.; Jimoh, E.; Clarke, O.; Olusegun, O. W.; Haleemah, B.A. 2011. Food and feeding habits of the African river prawn (Macrobrachium vollenhovenii, Herklots, 1857) in Epe Lagoon, southwest Nigeria. International Journal of Fisheries and Aquaculture, 3: 10-15.

Albertoni, E.F.; Palma-Silva, C.; Esteves, F.A. 2003. Natural diet of three species of shrimp in a Tropical Coastal Lagoon. Brazilian Archives of Biology and Technology, 46: 395-403. 
Alexander, C.G.; Hindley, J.P.R.; Jones, S.G. 1980. Structure and function of the third maxillipeds of the banana prawn Penaeus merguiensis. Marine Biology, 58: 245-9.

Andrian, I.F.; Barbieri, G. 1996. Espectro alimentar e variaçôes sazonal e espacial na composiçáo da dieta de Parauchenipterus galeatus Linnaeus, 1766, (Siluriformes, Auchenipteridae) na regiấo do reservatório de Itaipu, PR. Revista Brasileira de Biologia, 56: 409-422.

Barutot, R.A.; D’Incao, F.; Fonseca, D.B. Natural Diet of Neohelice granulata (Dana, 1851) (Crustacea, Varunidae) in Two Salt Marshes of the Estuarine Region of the Lagoa dos Patos Lagoon. Brazilian Archives of Biology and Technology, 54: 91-98.

Branco, C.W.C.; Aguiaro, T.; Esteves, F.A.; Caramaschi, E.P. 1997. Food sources of the teleost Eucinostomus argentus in two coastal lagoons of Brazil. Studies on Neotropical Fauna and Environment, 32: 33-40.

Branco. J.O.; Lunardon-Branco, M. J. 2002. Ecologia trófica de Portunus spinimanus Latreilli 1819, na armação do Itapocoroy, Penha, Santa Catarina. Revista Brasileira de Zoologia, 19: 723729.

Branco, J.O; Moritz JR, H.C. 2001. Alimentação natural do camarão sete-barbas, Xiphopenaeus kroyeri (Heller) (Crustacea, Decapoda), na Armaçáo do Itapocoroy, Penha, Santa Catarina. Revista Brasileira de Zoologia, 18: 53-61.

Branco, J.O.; Verani, J.R. 1997. Dinâmica da alimentação natural de Callinectes danae Smith (Decapoda, Portunidae) na lagoa da Conceição, Santa Catarina, Brasil. Revista Brasileira de Zoologia, 14: 1003-1018.

Chaves, P.T.; Umbria, S.C. 2003. Changes in the diet composition of transitory fishes in coastal systems, Estuary and Continental shelf. Brazilian Archives of Biology and Technology, 46: 41-46.

Chong, V.C.; Sazekumar, A. 1981. Food and feeding habitats of the white prawn Penaeus merguiensis. Marine Ecology Progress Series, 5: 185-191.

Collins, P.A.; Paggi, J.C. 1998. Feeding ecology of Macrobrachium borelli (Nobili) (Decapoda:Palaemonidae) in the flood valley of the river Paraná, Argentina. Hydrobiologia, 362: 21-30.

Coombs, E.F.; Allen, J.A. 1978. The functional morphology of feeding appendages and gut of Hippolyte varians (Crustacea, Natantia). Zoological Journal of the Linnean Society, 64: 261-82.

Cortés, M.; Criales, M.M. 1989/1990. Analisis del contenido estomacal del camaron titi Xiphopenaeus kroyeri (Heller) (Crustacea: Natantia: Penaeidae). Anales del Instituto de Investigaciones Marinas de Punta de Betin, 19: 23-33.

Ducan, C.C.; Ragood, R.W.; Frakes, T.A. 1975. Development of spawning and mass larval rearing techniques for brackish freshwater shrimps of the genus Macrobrachium (Decapoda, Palaemonidae). Florida Marine Research Publications, 12: 1-28.

Felgenhauer, B. E.; Abele, L.G. 1989. Evolution of the foregut in the lower Decapoda. In: Felgenhauer, B. E.; Watling, L. \& Thistle, A. B. (Eds.) Functional morphology of feeding and grooming in Crustacea. Rotterdan, A.A. Balkema. p. $205-219$.

Fonteles-Filho, A.A. 1989. Recursos Pesqueiros: Biologia e Dinâmica Populacional. Fortaleza: Imprensa Oficial do Ceará, 296p.
Garm, A. 2004. Mechanical functions of setae from the mouth apparatus of seven species of decapod crustaceans. Journal of Morphology, 260: 85-100.

Guerao, G. 1993-1994. Feeding habits of the prawns Processa edulis and Palaemon adspersus (Crustacea, Decapoda, Caridea) in the Alfacs Bay, Ebro delta (NW Mediterranean). Miscellania Zoologica, 17: 115-122.

Guerao, G. 1995. Locomotor activity patterns and feeding habits in the prawn Palaemon xiphias (Crustacea: Decapoda: Palaemonidae) in Alfacs Bay, Ebro delta (Northwest Mediterranean). Mararine Biology, 122: 115-119.

Guerao, G.; Ribera, C. 1996. Locomotor activity patterns and feeding habits in the prawn Palaemon serratus (Pennant, 1777) (Decapoda, Palaemonidae) in the Alfacs Bay, Ebro delta, Spain. Crustaceana, 69: 101-112.

Holthuis, L.B. 1952. A general revision of the Palaemonidae (Crustacea, Decapoda, Natantia) of the Américas. II. The subfamily Palaemonidae. Allan Hancock Foundation Occasional Papers, 12, 396 p.

Holthuis, L.B. 1980. FAO Species Catalogue. Shrimps and Prawns of the World. An Annoted Catalogue of Species of interest to Fiheries. FAO Fish, 1: 1-261.

Howard, R.K. 1984. The trophic ecology of caridean shrimps in an eelgrass community. Aquatic Botany, 18: 155-174.

Hyslop, E.J. 1980. Stomach contents analysis - a review of methods and their application. Journal of Fish Biology, 17: 411-429.

Inyang, N.M. 1978. Notes on the food of the Baltic Palaemonid shrimp Palaemon adspersus var. Fabricii (Rathke). Meeresforschung/ Reports on Marine Research, 26: 42-46.

Jayachandra, K.V.; Joseph, N.Y. 1989. Food and feeding habits of the slender river prawn, Macrobrachium idella (Hilgendorf, 1898) (Decapoda, Palaemonidae). Mahasagar, 22: 121-129.

Jimoh, A.A.; Clarke, E.O.O.; Whenu, O.; Adeoye, H.B. 2011. Food and feeding habits of the African river prawn (Macrobrachium vollenhovenii, Herklots, 1857) in Epe Lagoon, southwest Nigeria. International Journal of Fisheries and Aquaculture, 3: 10-15.

Kawakami, E.; Vazzoler, G. 1980. Método gráfico e estimativa de índice alimentar aplicado no estudo de alimentação de peixes. Boletim do Instituto de Oceanografia, 29: 205-207.

Krebs, C.J. 1989. Ecological Methodology. New York: Harper and Row. 654p.

Kunze, J.; Anderson, D.T. 1979. Functional morphology of the mouthparts and gastric mill in the hermit crabs Clibanarius taeniatus (Milne-Edwards), Clibanarius virescens (Krauss), Paguristes squamosus McCulloch and Dardanus setifer (MilneEdwards) (Anomura-Paguridae). Australian Journal of Marine and Freshwater Research, 30: 683-722.

Lewis, J.B.; Ward, J.; Mciver, A. 1966. The breeding cycle, growth and food of the fresh water shrimp Macrobrachium carcinus (Linnaeus). Crustaceana, 10: 48 - 52.

Lima, J.L.; Da Silva, T.C.; Da Silva, L.M.A.; Garcia, J.S. 2013. Brachyuran crustaceans from the bycatch of prawn fisheries at the mouth of the Amazon River. Acta Amazonica, 43: 93-100. 
Marte, C.I. 1980. The food and feeding habit of Penaeus monodon Fabricius collected from Makato river, Aklan, Philippines (Decapoda: Natantia). Crustaceana, 38: 225-236.

Meiss, D.E.; Norman, R.S., 1977. Comparative study of the stomatogastric system of several decapod crustaceans (I. Skeleton). Journal of Morphology, 152: 21-54.

Odinetz-Collart, O. 1988. Aspectos ecológicos do camaräo Macrobrachium amazonicum (Heller, 1862) no Baixo Tocantins (PA-Brasil). Memoria Sociedad de Ciencias Naturales La Salle, 48: $341-353$.

Roy, D.; Singh, D.S.R. 1997. The food and feeding habits of a freshwater prawn Macrobrachium choprai. Asian Fisheries Society, 10: 51-63.

Salindeho, I.R.; Johnston, D.J. 2003. Functional morphology of the mouthparts and proventriculus of the rock crab Nectocarcinus tuberculosus (Decapoda: Portunidae). Journal of the Marine Biological Association of the United Kingdom, 83: 821-834.

Sharma S.; Subba, B. R. 2005. General biology of freshwater prawn, Macrobrachium lamarrei (H. Milne-Edwards) of Biratnagar, Nepal. Our Nature, 3: 31-41.
Silva, M.C.N.; Frédou, F.L.; Souto-Filho, J. 2007. Estudo do crescimento do camarão Macrobrachium amazonicum (Heller, 1862) da Ilha de Combú, Belém, Estado do Pará. Amazonia: Ciência e Desenvolvimento, 2: 85-104.

Simonian, L.T.L. 2006. Pescadores de camarão: gênero, mobilização e sustentabilidade na ilha Trambioca, Barcarena, PA. Boletim do Museu Paraense Emílio Goeldi-Ciências Humanas, 1: 35-52.

Suthers, I. M. 1984. Functional morphology of the mouthparts and gastric mill in Penaeus plebejus Hess (Decapoda : Penaeidea). Australian Journal of Marine and Freshwater Research , 35: 785-792.

Williams, M.J. 1981. Methods for analysis of natural diet in portunid crabs. (Crustacea: Decapoda: Portunidae). Journal of Experimental Marine Biology and Ecology, 52: 103-113.

Wootton, R.J. 1992. Fish Ecology: Tertiary Level Biology. Blackie, London, 212p.

Zar, J.H. 1996. Biostatistical Analyses. Third Edition. Prentice Hall, New Jersey, USA. 121p.

Recebido em 22/02/2013

Aceito em 13/08/2013 
